\title{
Determining the impact of information on rural livelihoods and sustainable tourism development near protected areas in Kwa-Zulu Natal, South Africa
}

\author{
FA Fairer-Wessels
}

Division of Tourism Management, Faculty of Economic and Management Sciences, University of Pretoria, Pretoria, South Africa

\begin{abstract}
It is well known that tourism can bring problems for poor rural people in less developed countries. This paper describes a pilot study of five rural communities in the vicinity of or within a South African protected area, the iSimangaliso Wetland Park. Within the context of sustainable tourism development and the sustainable livelihoods approach, it explores whether access to information and to education and training impacts on the survival of these communities. The information provision role of governing authorities is also investigated regarding the preservation of the site and also for ownership and land claims. The results indicate that lack of access to relevant information can be a prime reason why rural communities cannot break out of the poverty cycle, and they suggest it is imperative to train and educate survivalist communities so that they can mobilise themselves economically, including through local tourism development. The demonstrated significance of lack of information provision, training and education represents a new contribution to the field. The study concludes that, where it is a matter of survival for rural communities, a sustainable livelihoods approach may be more appropriate and attainable than a sustainable tourism development approach.
\end{abstract}

Keywords: sustainable tourism development; livelihoods approach; rural communities; information provision. 


\section{Introduction}

More than a decade ago, Tosun (2000, p. 625) observed that "the biggest challenge for the poor in many local tourist destinations in the developing world appears to be mere survival, which occupies all their time and consumes their energy". A pilot study was undertaken of five geographically spaced communities adjacent to, and also within, the iSimangaliso Wetland Park. This area, a World Heritage and Ramsar Site, was selected due to its sensitive natural heritage and exceptional biodiversity that man is impacting on. The aim was to determine, within the context of sustainable tourism development and the sustainable livelihoods approaches, whether access to information and education had an impact on the survival of the impoverished and largely unemployed communities residing in this area. Consideration is given to whether the governing authorities provided information and supported land claims within the site; whether these communities were provided with information and education regarding the importance of preserving the natural site; and whether the communities had general access to information and education to sustainably improve their livelihoods.

The study relates to existing research. This includes work by Ellis (2006) on rural households that mix agricultural and non-agricultural activities in terms of livelihoods diversification; by Hopwood et.al (2005) and Scoones (2009) that discuss sustainability as an integral element of the livelihoods framework and captures the complex interactions between people and their natural resource base; by Jacobs and Makaudze (2012) in South Africa's West Coast District that emphasizes the need to gain a deeper understanding of rural livelihoods within the sustainable rural livelihoods approach and of obstacles to access to education for the rural poor; and by Juru (2012) that focuses on rural coastal communities in Northern Kwa-Zulu Natal. The present paper builds on this past research on sustainable rural livelihoods.

The aim of this exploratory qualitative research was to determine, within the context of sustainable tourism development and sustainable livelihoods approaches, whether access to, 
and availability of, information and education and training has an impact on the survival of the selected communities. The specific objectives were to determine:

- $\quad$ whether the authorities (i.e. iSimangaliso Wetland Park Authority (iWPA), Ezemvelo KZN Wildlife, Departments of Agriculture, Forestry \& Fisheries (DAFF), and Environmental Affairs and Tourism (DEAT)) provided information to the selected impoverished communities and supported their ownership and land claims;

- whether the selected impoverished communities were provided with information and education regarding the importance of preserving the Wetland Park as a natural resource for sustainable livelihoods and sustainable tourism development;

- whether the selected impoverished communities had general access to training and education to sustainably improve their livelihoods through sustainable tourism development.

\section{Sustainable development, sustainable tourism and sustainable livelihood}

A widely used definition of "sustainable development" from the World Commission on Environment and Development is that it is development that meets the needs of the present without compromising the ability of future generations to meet their own needs (UN, 1987). Sustainable development promotes the idea that social, environmental, and economic development is achievable while protecting the earth's natural resources. The UNWTO suggest that the aims of sustainable tourism are (UN, 1987, UNEP \& UNWTO, 2005, p.11) to:

- make optimal use of environmental resources that constitute a key element in tourism development, maintaining essential ecological processes and helping to conserve natural heritage and biodiversity;

- $\quad$ respect the socio-cultural authenticity of host communities, conserve their built and living cultural heritage and traditional values, and contribute to inter-cultural understanding and tolerance;

- $\quad$ ensure viable, long-term economic operations, providing socio-economic benefits to all stakeholders that are fairly distributed, including stable employment and income-earning opportunities and social services to host communities, and contributing to poverty alleviation.

In the 1960s, mass tourism, although providing economic growth opportunities, caused irreversible damage to the environment and society (Spenceley, 2005). To counter this trend, 
development needs to become more sustainable (Kuhn, 2007), and sustainable development that previously focused on mining, forestry, manufacturing and fisheries (Govender VanWyk, 2007, Muhanna, 2008, Rogerson \& Visser, 2004) has at times started focusing on tourism (Kuhn 2007). Definitions of "sustainable tourism" therefore take into account broader principles of sustainable development and build on advances in sustainable development research (Kuhn, 2007).

The UNWTO definition maintains that sustainable tourism is "tourism that takes full account of its current and future economic, social and environmental impacts, addressing the needs of visitors, the industry, the environment and host communities" (UNEP \& UNWTO, 2005, p. 12). This definition encompasses broad principles of sustainable development since it takes into account the key role of different players in sustainable tourism, and regards sustainable tourism as important for facilitating equity in the bond between the environment and people (Lee \& Jamal, 2008), and it is used in this paper.

Sustainable tourism development requires informed participation of relevant stakeholders and political leadership to ensure wide participation and consensus building (UNWTO, 2000). The World Travel and Tourism Council's mission statement embeds the sustainable growth of travel and tourism. It maintains that impacts on natural and cultural environments should be positive, that sustainable growth should provide benefits for all sectors of society including young children, women and indigenous people, that a skilled workforce should be developed, that demand for sustainable products should be stimulated and that technology should be used for innovative solutions (WTTC, 2013).

In South Africa the role of communities in sustainable tourism development has been 
strongly recommended in a series of national policies over the past decades. A 1996 White paper encouraged communities to seek private sector partnerships in areas of sustainable tourism development (Department of Environmental Affairs and Tourism); a 2002 UN Conference on Environment and Development World Sustainability Forum hosted in South Africa set sustainable development targets (DEAT, 2002); a Protected Areas Act regulated community access to natural resources in coastal forestry areas (EKZNW, 2011); and the National Tourism Sector Strategy (Republic of South Africa, Department of Tourism 2010) endorsed tourism growth for community benefit so as to create jobs and alleviate poverty. However, little progress has been realized since 2002, and in 2013 a new 'Growth Path' (Republic of South Africa, 2001) and Industrial Action Plan (Department of Trade and Industry, 2013) again earmarked tourism as a growth sector to contribute to rural area development, economic growth and the creation of decent work and sustainable livelihoods (Department of Trade \& Industry, 2013). But it can be argued that by 2015 none of the above policies had yielded much substantial benefits.

Within this context Tao and Wall $(2009$, p. 97) maintain that "sustainable development" and "sustainable tourism" have conceptual deficiencies and have yet to provide practical guidelines for the development of marginal communities where the move towards sustainability may be challenging. They propose "sustainable livelihoods" as a more practical hands-on approach to help alleviate poverty, increase rural development and sustain the environment (Chambers \& Conway, 1992; Ellis, 2000; Jacobs \& Makaudze 2012; Manwa, 2014; Spenceley \& Meyer, 2012). With this as background, the National Department of Tourism is currently embarked on developing operational guidelines to support the development and management of sustainable community-based tourism through a consultative process with relevant stakeholders. 
In 1992 Chambers and Conway (p.7) defined a sustainable livelihood as one that "comprises the capabilities, assets (both material and social resources) and activities required for a means of living" and that a livelihood is sustainable when it can cope with and recover from, maintain or enhance its capabilities and assets, while not undermining the natural resource base; based on this, Scoones (1998) developed a sustainable rural livelihoods framework.

Apleni (2013) argues that a wide range of actions are needed to increase benefits to the poor from tourism that go beyond promoting community participation. He also contends that many community-based tourism projects funded by donors and NGOs have had little success. Communities' lack of enthusiasm when they realise that few benefits trickle down to them from the tourism industry is an obstacle to community participation (Tosun, 2000). A case study of two tribal communities - Mabaso and Mbila, on Lake Sibaya in Kwa-Zulu Natal (Van Rooyen, 2003) - illustrates this. Here two tourism facilities were developed, a houseboat and lodge, one for each community. The communities' dissatisfaction with the economic benefits from these developments led to tribal rivalry and conflict and both developments were subsequently sabotaged by the other and eventually deserted. The case study demonstrates how conflict can result in economic loss for developers and communities where tangible benefits do not reach the communities and where "people in tourism" are the only beneficiaries.

Jones (2006) affirms that conflict and contestation over coastal areas can exist between local communities and eco-tourism enterprises in Kwa-Zulu Natal. That study suggests that the failure of ecotourism ventures to transform the socio-economic situation of rural communities indicates that communities are losing their power, control and access to natural resources that allow them to sustain themselves. Although conservation and tourism activities should be mutually supportive (Duffy, 2001), they actually often collide (Mbatha, 2011) in that little 
economic benefit accrues to communities due to high 'leakage' in the tourism industry, with profits retained away from the area of operation. These studies corroborate findings by Tosun (2000), Saarinen (2010) and Apleni (2013) that indicate that local people may lose control over local tourism development because of a lack of awareness about information or poor dissemination of information. Thus, the present papers seeks to explore how communities might be better informed.

\section{Rural communities and (sustainable tourism) development}

Rural communities in South Africa have not been active stakeholders in tourism development. In this context further investigation is needed as to whether such communities are aware and have access to information and education regarding the preservation of natural and cultural heritage through sustainable tourism development for sustainable livelihoods (Gumede, 2009; Nzama, 2008; Saarinen, 2010). These issues are examined for selected areas adjacent to, and within, the protected iSimangaliso World Heritage Wetland Park in KwaZulu-Natal (KZN), South Africa, and especially among community members that were unemployed at the time of the research.

A study by Nzama (2008) on the ecological management of iSimangaliso Wetland Park indicates that although some respondents (KZN Ezemvelo officials and business owners) were positive about tourism development, the local community was outraged at legislation that banned 4x4 vehicles on Sodwana Bay beach and also prohibited persons under 15 from participating in informal employment (www.labour gov.za, Child Care Amendment Act, 1991), as that legislation deprived communities of tourism income (Nzama, 2008; Van Rooyen, 2003).

Nzama (2008) maintains that World Heritage Site authorities should encourage local communities working in the Park to participate fully in activities and educational programs so as to enhance their understanding of nature and ecosystems. But Nzama only researched the opinions of local community members working and living in the Park that were aware of the 
importance of protection of biological diversity, tourism development and park management. Juru (2012) also interviewed employed community members on socio-economic and ecological issues within and outside of the Park. Yet neither Nzama nor Juru examined the views of unemployed rural impoverished communities, with this being the focus of this study.

To encourage employment opportunities, researchers (Arcodia \& Whitford 2006; Dlamini 1999; Larlham 1981; Prentice \& Andersen 2003; Saarinen, 2010; Van Zyl \& Botha 2004; and Zibani 2002) agree that local communities might usefully engage in sustainable tourism development initiatives in order to generate economic benefits,. That might involve, for example, authentic cultural festivals and rituals to conserve local heritage and craft development to promote tourist visitation. Yet education and training in basic tourism skills remains necessary to help rural communities find jobs, access the tourist market and bring benefits to them (Ashley \& Jones, 2001; Botha, 2006; Okazaki, 2008, Van Rooyen, 2003). Qua-Enoo (2001) is of the opinion that the tourism sector can provide a direct market as well as advice and support to community members.

The lack of success of sustainable tourism initiatives in South Africa may be attributed in part to rural communities' lack of information and education regarding involvement in tourism development. Compounding the problem is that rural communities are struggling to meet basic needs, with daily survival taking precedence over higher needs, and with participation in tourism development not seen as a priority by these communities (Apleni 2013; Saarinen 2010; Tao \& Wall 2009; Tosun 2000).

\section{The iSimangaliso Wetland World Heritage Site}

The Greater St Lucia Wetland Park was proclaimed in 1999 under the World Heritage Convention Act. As far back as 1895, 16 parcels of land were consolidated to create an integrated protected area of over 239,566 ha stretching $220 \mathrm{~km}$ along South Africa's coast fronting the Indian Ocean. In 2008 after extensive consultation the new name iSimangaliso ('miracle' in isiZulu) was gazetted for this wetland park. 
The Park consists of two marine protected areas, the St Lucia and Maputaland marine reserves, and 11 non-marine areas. Its exceptional biodiversity and ecological processes justify its protection. Its five distinct interlinked ecosystems, with rich microhabitats of mangrove, coral reefs and raffia-palm forests, include a coastal and marine system, eastern shore dune forests, estuary and lake systems, Mkhuze River papyrus swamps, and drier acacia savanna of the Western shore. The Park also contains four Ramsar sites: the St Lucia Lake system, Turtle beaches/Coral reefs of Tongaland, Kosi Bay Lake system and Lake Sibaya. A site is designated a Ramsar Wetland of International Importance if it meets any one of seven criteria, and remarkably the St Lucia Estuary System meets all seven of these criteria, while the other three sites conform to at least one of them (Briggs, 2006).

The Park environment is currently threatened in a number of ways. For example, the ecology and health status of Lake St Lucia is compromised by less water flowing into the Umfolozi river that feeds the lake. In the 1930s, the upper Umfolozi swamps were drained to make way for sugarcane and in drought the lake receives little water, and that places stress on the ecosystem. The Umfolozi River has also been diverted so that it flows directly out to sea, threatening to breach a sand bar, and thus increasing sedimentation and invasion of the land by sand and seawater. Serious droughts have increased Lake St Lucia's salinity and killed off the shoreline vegetation, causing bank erosion and silting of the lake. Further threats have been overuse of resources (such as unsustainable fishing), land claim issues by local communities, infestation by alien invasive plants, and the grounding of an oil tanker in 2002 . Added to that there has been irresponsible and unsustainable tourism development.

\section{Governance of tourism and the iSimangaliso Wetland Park Authority (iWPA)}

Effective governance is essential for achieving the management and conservation objectives of a world heritage site: "It is not sufficient to have the right numbers of protected areas in the right places, it is also necessary to ensure that their governance is able to manage them in an effective manner and produce the desired outcomes" (Dearden, Bennet \& Johnston, 2005, p. 98). Protected area governance should include both social and ecological concerns 
within the basics of decision-making (Eagles, Romagosa, Buteau-Duitschaever, Havitz, Glover \& McCutcheon, 2013, Ruhanen, 2013).

The iWPA was established as the dedicated management authority to manage the park according to site regulations of the South African World Heritage Convention Act and the UNESCO World Heritage Convention (James, 2012). Participation by a wide range of major stakeholders, including local communities, can enhance the democratic process and sense of ownership associated with sustainable tourism (Bramwell \& Lane, 2011). The United Nations Development Programme (UNDP, 1997) specifies 10 criteria for good governance: public participation, a consensus orientation, a strategic vision, responsiveness, effectiveness, efficiency, accountability, transparency, equity and the rule of law, and the iWPA is attempting to implement those considerations.

The iWPA has the capacity and resources to carry out what is probably its most important leadership task: the alleviation of poverty to promote development in villages whose conditions could be described as a "paradox of poverty amidst the plenty of nature". The iWPA has launched a major program in the Park to build and manage the existing tourism market by providing empowerment activities, with the activities including ownership, job creation, procurement and training to stimulate economic growth. This program may however be futile given South Africa's 25\% unemployment rate and its dire education system. Forty years ago Harbison (1973, p.3) observed "that if a country is unable to develop the skills and knowledge of its people and to utilise them effectively in the national economy it will be unable to develop anything else". Two decades later, Woodley (1993, p.143) argued that "without a trained local workforce the industry can only function by importing staff, in which case the principle of ensuring local benefits from tourism is 'thwarted"'.

The daily management of the Park is undertaken by Ezemvelo KZN Wildlife (EKZNW), a provincial agency mandated to carry out biodiversity conservation, tourism and community development. These activities are complex and they require good governance and leadership. 


\section{The study sites}

Tourists that travel to northern Kwa-Zulu Natal are offered the image of an untouched landscape that is preserved in its natural beauty (DEAT 1998). For this pilot study five sites in the vicinity of, and within, the iSimangaliso Wetland World Heritage Site were selected at random to represent a geographic spread of communities. These five communities were located either in the Park or in its buffer zone in the District of uMkhanyakkude. The sites were the municipality of Mtubatuba (including St Lucia town) in the southern region of the Park; Bangizwe town and adjacent rural community; Sodwana Bay Municipality and the rural village of Mbazwana in the middle region; and uMhlabuyalingana District Municipality (including the rural communities of Kosi Bay/KwaNgwanase/eManguzi) in the northern region. St Lucia, Sodwana Bay and Kosi Bay were selected as coastal areas with tourism activity and development, and the other two, the districts of Bangizwe and Mbazwana, were selected as they are geographically in between the other three, they are inland and they have little if any tourism activity.

Successful community-based tourism operations exist in the vicinity of St Lucia. They include the popular tourist Khula Village, where tradition meets contemporary Zulu society with singing performances, local cuisine and daily life re-enactments (Gumede, 2009); the Iphiva Trail, a birding hotspot; and the Rasta Community Trail in the Dukuduka coastal forest (with indigenous butterflies at Isiphaphalazi). These tourism operations are within the protected area of the Park, and the associated conservation activities means that access into these areas is challenging for community members (Juru, 2012).

Sodwana Bay, an environmental destination with recreational and tourism value is a deep sea fishing and scuba diving spot where local community members offer specialised services 
to foreign and local tourists. Community-based tourism operations here include the iSimangaliso Guided Walking Safari, and the Bhangazi Horse Safaris along untouched beaches for wildlife viewing. Local communities are involved in these tourism activities both for jobs and their own recreational purposes (Nzama, 2008). Recreational activities, however, are the least of their priorities as they are more concerned with the basic socio-economic challenges of providing livelihoods for their families.

Kosi Bay in northern KZN, where African tribal culture can authentically be experienced, is without conventional electricity and water supply. Only accessible on foot, horseback or with $4 \times 4$ vehicles, this area is sheltered from human intrusion and mass tourism. Where tourism activities occur in these protected areas, traditional land use practices may be reinforced or inhibited by both conservation and ecotourism operations, such as at the Ndomo Game Reserve and the Kosi Bay Hiking and Slackpacking Trail. The latter Trail, an adventure tourist's dream, is led by local guides and is one of the country's most inaccessible, consisting of four interconnected lakes with traditional, century-old Tonga fish traps and an estuary. Fossilised corals on high dunes and loggerhead and leatherback turtles can be viewed while tasting locally crafted lala palm beer. The trail emphasises sustainable tourism development and brings together local Kosi Bay lodges, Bush camps, local communities and guides.

In post-apartheid South Africa, tourism and particularly tourism in rural coastal communities (DEAT, 2009) has been regarded as a national strategy and development option for economic growth, community development and poverty relief. Unfortunately, unstructured and uncoordinated tourism development without proper authorization from provincial or national government has not delivered substantial livelihood benefits to rural communities, just as the 
hosting of the 2010 FIFA Soccer World Cup also did not provide the anticipated economic stimulus for the region.

The five research sites taken together cover the length of the iSimangaliso Wetland Park, stretching from St Lucia in the south to Kosi Bay in the north. As a pilot study, the rationale was to obtain a broad overview of whether community members in these rural village communities held similar views concerning access to information and education and concerning how tourism development in the Park affected or could affect them.

\section{Research methods}

This study was based on qualitative analysis using focus group discussions and in-depth interviews with local community stakeholders in the study area. The data was analysed using content analysis, which indicated the importance of interacting with a variety of the groups involved: community members (unemployed) at grassroots level, stakeholders at regional and government level, and local tourism operators. This clarified the complex relationships between these groups with regard to sustainable development, and with identifying issues that may directly affect the livelihoods of community members. It was especially helpful to determine how community members viewed their situation in terms of access and availability of information regarding issues that affected their livelihoods, ownership and land claims, preservation of the wetland and the associated role of the authorities, and the education and training of local residents, including existing and potential tourism opportunities.

Focus group discussions were held to gain an understanding of the target community; and indepth interviews were conducted with purposively chosen stakeholders, namely information rich members of the selected communities. The interviews used the same interview schedule which addressed the study objectives and helped to direct the discussions. 
The population of the five focus group discussions was 42 unemployed adult community members who were available at the time of the study using non-probability convenience sampling (Cater \& Low, 2012; Du Plooy, 2009). There were. 12 participants at Mtubatuba, 7 at Bangizwe, 6 at Sodwana Bay, 7 at Mbazwana, and 10 at Kosi Bay. Oral discussions were held (and recorded) in the local vernacular (isiZulu) by a local experienced fieldworker due to the high rates of illiteracy among adults.

In-depth personal interview respondents were selected for their knowledge pertaining to the objectives, using non-probability purposive sampling (Keyton, 2011). A total of 19 knowledgeable and employed interviewees were interviewed from the five selected communities, including senior teachers, representatives of the iWPA and Ezemvelo KZN Wildlife, Education District representatives, officials from DAFF, local tour operators from Sodwana Bay, St Lucia/Mtubatuba and Kosi Bay (who were contacted by phone after the fieldwork), and community elders (indunas) from Bangizwe and Mbazwana.

\section{Findings and discussion}

In analysing the transcripts for the focus group discussions and interviews, respondents' perspectives were grouped according to the study objectives and the issues covered in the interview schedule.

Access to information on land claim and land ownership issues

Land claimant communities are descendants of the original inhabitants of the land living in the Eastern Shores State Forest, Cape Vidal State Forest and Sodwana State Forest. The iWPA supports the Regional Land Claims Commission in settling land claims that have been lodged on land in the Park.

In-depth interviews with representatives of the iWPA revealed that they take responsibility for the implementation of settlement and co-management agreements that are negotiated with landowners. Title to land within a protected area is transferred to successful claimants but no physical occupation of the land takes place and the land continues to be managed as an 
integral part of the Park. Each settlement agreement contains arrangements for compensation and benefits to land owners. The iWPA has facilitated the settlement of nine major land claims and it has a land inclusion policy incorporating private and communal land on the Park's fringes (James, 2012).

In-depth interviews with representatives of iSWPA and Ezemvelo KZN Wildlife revealed that the empowerment of land claimants and communities living in and around iSimangaliso is assisted by them being mandatory BBBEE (Broad-Based Black Economic Empowerment) partners, and this is a key aspect of iWPA's commercial policy. The Authority regards transforming the tourism sector as central with equity partnerships between private and community partners; there is job creation and employment equity in tourism facilities and activities, and in the procurement of goods and services from local entrepreneurs and small businesses. At Sodwana Bay a local snack stall entrepreneur on the beach said "business is good during school holidays because [visiting] children always wanted to buy cola and Simba [chips]"; while a fishing vessel owner/entrepreneur that takes fishermen [tourists] out to sea said "I know where the good fish bite... and I always clean the fish afterwards ...but these areas are not for us, they are for the rich people to enjoy..."

The focus group discussions revealed that potential landowners and claimants had sufficient access to land claim information from the iWPA, and that they were sufficiently informed and supported by them. Some male elders in the Mtubatuba group stated that "the people from the Authority told us about the problems with land that belonged to our forefathers in the Park, and that it is was not always easy [to prove ownership]". A respondent in the Kosi Bay focus group discussion agreed that the iWPA was helpful with land claim issues, and he said that he knew someone who had been successful with such a claim, as "this land had been in that man's family for many, many years... and he gets money for it from the Park because he cannot live there". 
Information and education regarding the preservation of the Wetland Park

Jamal and Stronza (2009, p. 171) state that although conservation and tourism could be considered symbiotic, they are generally conducted by very different organisations within and outside a destination (such as a protected area), and that can create a gap in information flow, with resulting difficulties for destination development. Wellings' study (2007, in Jamal \& Stronza 2009, p. 172) mentions four principles in the Aboriginal people's Management Plan for the Kakadu World Heritage Area, Australia. Two of these principles are relevant to this study, namely, "caring for country" (this principle recognises that conservation of unique natural and cultural heritage is essential for park management, and that Aboriginal people have a role in protecting the Park as well as in the Park's World Heritage values). The second principle involves "telling people about the park" (which is done through interpretative programs to communicate park heritage and values to tourists and the broader public, with this being integral to park management). These principles are relevant to the iSimangalsio Wetland Park in terms of conservation and of creating awareness of the Park among locals and tourists, and they have a significant tourism development dimension.

Unemployed focus group respondents agreed that the Wetland is important and must be preserved, but they expressed concerns about climate change and how the Park can be protected. They did not consider it their duty to protect the Park as they felt they had no authority and they considered that such protection was the responsibility of iWPA and Ezemvelo KZN Wildlife. The men were mainly concerned about the drying up of water in the rivers and lakes, to the extent that it was now possible to "walk on the dry riverbeds", and also the severe decrease in fish. They recalled the forest area of the Park as previously rich in wildlife, and they were disillusioned with the authorities, who they felt were not fulfilling their duty to preserve the site by controlling over-fishing and hunting. Many felt it the duty of the local municipal office to communicate to the community the effects of overfishing and the need for legal licenses, since people were resorting to fishing for survival. The men also said the historical planting of pine and eucalyptus plantations caused ground water depletion and that they had reported this, without effect, to the DEAT years ago. Since the granting of 
World Heritage status to the Park in 1999, these plantations around the lake have been removed so as to increase water seepage.

The (unemployed) women in the focus group discussions said they personally were "not doing anything to preserve the site", nor had they seen much effort on the part of the local municipal office.

In-depth interviews revealed that impoverished rural communities were dependent on primary activities, such as hunting, fishing and subsistence farming, but that these were severely affected by drought and the drop in water levels. The interviewees said that the communities were ignorant regarding a suitable time to farm, indicating the lack of relevant basic information that the DAFF should provide. Livestock, the community's economic base, was also perishing from drought that affected both the livelihoods and cultural traditions of communities as cattle and goats are needed for traditional ceremonies. Interviewees said that communities needed both information and training about basic farming methods and about other vocations so as to "lift them out" of basic day-to-day survival to more sustainable livelihood opportunities.

Some of the interviewees said that Wetland protection was important since most indigenous trees had been harvested by communities for firewood, and that there was illegal fishing and hunting for livelihood purposes. The focus group findings indicated that impoverished communities did not take "ownership" of the preservation of the site, although they regarded protecting nature as important in order to access natural resources for their survival. This is in contrast to Nzama's (2008) study, where community respondents employed in the Park felt that protecting the ecosystems was everybody's responsibility.

The findings indicated there was a lack of sufficient information disseminated from the authorities in order to inform communities about the importance of preservation. They also 
indicated that ward councillors with political influence should play a more prominent role with regard to sustainability and site preservation as this could pave the way to develop tourist activities (Jones 2006), although this implies the need for skills training in tourism. The findings, however, also indicated that most unemployed, unskilled community members focused on basic survival and could not imagine themselves being involved in tourism activities as they felt they were too ignorant and uneducated to engage in them, although some were keen to receive skills training.

The iWPA however, noted the importance of fostering conservation awareness, especially among the youth, and providing basic information on environmental awareness through local schools. Adult respondents not employed by the Park were not considered in environmental awareness training and their opinions differed from those employed in the Park, with this supporting findings by Nzama (2008).

\section{Availability of, and access to, information and education for sustainable livelihood} development and sustainable tourism development

Coastal tourism encompasses a wide range of tourism, leisure and recreational focused activities that take place in and around the coastal zone and coastal waters, such as accommodation, restaurants, and supporting infrastructure (Hall, 2001). Focus group respondents, however, were more concerned about farming and climatic conditions, that is, sustainable livelihood activities, than with tourism activities as they felt they first needed to be informed and trained for employment in tourism. Consequently, tourism staff were largely sourced from urban areas.

Focus group respondents also said that information and education for sustainable livelihood activities (e.g. crop growing and farming) was made only available to men in the community and local indunas (knowledgeable community elders) through personal visits by 
representatives of the DAFF and Ezemvelo KZN Wildlife. Although information pamphlets were distributed they were inaccessible due to the low literacy levels.

However, sustainable tourism development is undermined by survivalist practices such as illegal fishing and harvesting indigenous trees. One male stated that "people from DAFF must check whether fishermen have licences to fish in all seasons as they catch lots of fish all year round and sell them to us for too much money". Male respondents in Kosi Bay said that "utshwayelo [fish traps with a 700-year-old tradition] in the estuary, belong to families and cannot be used by other community members, and that some people fish illegally and unsustainably without the councillors doing anything [such as by providing information about sustainable fishing practices]". Yet some male respondents mentioned turtle nesting areas at Bhanga Nek Turtle Research Station where "trained Thonga community guides with annual concessions take tourists to experience loggerhead and leatherback turtles laying eggs at night". Here the "Turtle Tour proceeds go directly to the local Thonga community living at KwaDapha and Bhanga Nek.

Other focus group males said that wood artisans carve sculptures for tourists for a living using indigenous trees such as the umkhuhlu and umganu, and once one area is exhausted they proceed to another. These wooden tourist artefacts are a conservation threat and they are not beneficial to sustainable tourism practices. This activity indicates a lack of awareness and information amongst impoverished communities about the long-term effects of such harvesting. Trees were also harvested for muthi (medicinal) purposes and they said that the once dense forest was now almost gone, although they added that people needed to survive and that local indunas' authority did not control over-harvesting. (Words in italics refer to the indigenous words in isiZulu). Another male commented that the "wood carvers 
cut the old trees that are very few in the forest, and...the officials don't tell them to stop cutting the trees - they are from the time of our forefathers and must be kept [for our children]". Some participants agreed that the DAFF should be tasked to make locals aware at workshops of the dire consequences of felling indigenous trees both for tourism products and survival purposes (firewood). Tree planting should be encouraged on a continuous basis to "educate" the communities on "how to" preserve the site.

Some focus group females revealed that annually (in May) about 3500 rural women take part in the traditional harvesting of reeds at the iNcema festival. They travel to iSimangaliso to collect the reeds in selected areas for the year's craftwork, with rotational harvesting practiced in order to ensure minimal impact and sustainable use of the resource. This festival if marketed properly has significant tourism potential among cultural tourists, and the resulting craftwork can be sold directly to tourists or through speciality shops. However, the women stated that they needed training to create crafts (baskets and mats) that are more suitable to attract local and foreign buyers, and not overly traditional styles.

Some focus group females confirmed their total exclusion from information by the authorities. They only obtained information from women who had been informed by their husbands, or by listening on mobile phones (although the signal was usually poor) or by listening to mother tongue presenters on the community radio. They were very keen to obtain relevant information to improve their livelihoods, and they wanted information provided personally and orally "by people higher up" (i.e. people with authority). Water shortage, for example, was their foremost domestic problem and they had attended meetings to address this, especially in Bangizwe and Mbazwana where they stated that "we have been struggling to get water for a long time to grow our crops [for sustainable livelihood development] and 
the people [officials] just come and then go away". They also mentioned noticing the "skin and bones of dead animals", and "tortoises and crabs, crawling slowly in the dry soil" searching for water due to the drought.

Gender inequalities bear directly on women's access to resources, and inequality in power and participation leads to inequality of benefits sharing and livelihoods, as well as influencing local development. From a livelihood perspective, women are marginalized and face the harshest impacts to their livelihood survival strategies (Juru 2012), and also in the Park they suffer from limited access to information.

Although the tourism sector in South Africa is suggested to be able to provide new and alternative livelihoods to rural communities through attracting (national and international) investors, which should benefit the locals and it is in a context where tourism should take place, this is often not the case (Juru 2012).

Some of the interviewed teachers indicated that the Department of Education should refocus the curriculum on tourism, business management and home economics and encourage 'nature conservation' through bursaries for pupils. The Departments of Education and Environmental Affairs should also collaborate in educating, training and making pupils aware of the benefits of tourism and importance of preserving the Wetland as a World Heritage site. By involving and informing children they can in turn create awareness among their uneducated/illiterate parents about the various issues and importance of preserving the environment, which is also an area that can be investigated.

Many respondents agreed that education and training could be the catalyst to sustainable livelihood and tourism development, but they indicated that they did not know how to access 
available information about training possibilities and that money remained a major deterrent.

\section{Recommendations for sustainable livelihoods and tourism development}

\section{Climate change and the environment}

Focus group respondents were often aware of climate change and its dire effects on the environment and their livelihoods, but they felt that ensuing problems (shortage of water, overfishing and depletion of wood) were the authorities' responsibility. Participants were merely "living with the problem". The local authorities could explain this through the sustainable livelihoods approach by using a simple analogy (Tao \& Wall, 2009, p. 97); for instance: "sustainable livelihood development is when you are planting new crops and you are preparing the soil properly so that you can re-use it the following season" or "sustainable livelihood development is when you are fishing for crabs and you throw back the small crabs into the lake so that they can grow up, because if you eat all the little crabs there won't be any left to grow up and produce baby crabs - you will have eaten the whole lot". A sustainable livelihood therefore comprises skills such as agricultural skills, assets and activities required for a means of living; and the livelihood is sustainable when people can cope and recover from misfortune and maintain (or improve, such as annual crops to harvest) their skills and assets, while not undermining the natural resource base, such as through over-fishing and using indigenous wood for carving (Chambers \& Conway, 1992).

\section{Tourism developments are usually small-scale}

Communities need to be made aware that local tourist developments are usually small in scale and likely only to contribute in part to a community's socio-economic situation, and that they are not likely to be the primary solution to the socio-economic uplift of an entire community. In-depth interviews and focus groups revealed that transparent communication and collaboration between communities, authorities and stakeholders in tourism development is lacking. Respondents felt it the responsibility of various authorities, from municipal, 
provincial and national level, to implement training and skills transfer programs for the community, aiming for the sustainable livelihoods approach and supporting sustainable tourism operations within the natural and cultural resource base.

\section{Information dissemination}

Interviewees from DAFF and Ezemvelo KZN Wildlife suggested there was a role for indunas (community leaders) as community information providers to orally disseminate information and to practical demonstrate/role-play about the sustainable livelihoods approach and responsible tourism practices. Some participants indicated that ward councillors should also play a practical hands-on role in providing information on sustainability issues, since they are politically influential and people listen to them.

\section{Sustainable development education}

Sustainable development education by local authorities through community workshops is essential, especially for survival in the context of climate change. Opportunities could be created for impoverished community members to learn a variety of craft making skills and other occupations, to make them less reliant on their natural resource base for survival. As an example, kitchen stoves working off biofuel, instead of using conventional wood, have been developed, and rural communities could be taught to use these to alleviate stress on the remaining indigenous forests. This could also assist towards achieving Millennium Development Goal 1 by relieving hunger and poverty; Millennium Goal 3 by promoting gender equality; and Millennium Development Goal 7 by encouraging environmental sustainability.

\section{Conclusion}

A limitation of this study - as a pilot study - is the small number of focus group respondents and interviewees, given that in 2004 around 45,000 people (StatsSA, 2004, p.10-11) lived in the immediate vicinity of the protected area, with an estimated 100,000 people currently 
living there. A comprehensive stratified survey of the whole area to identify a wider spread of local communities than are covered by this pilot study would be of value, focusing specifically on unemployed community members, as their buy-in is important in preserving the natural resource base through obtaining relevant information and access to education through skills development to enhance their sustainable livelihoods, and in potentially empowering them through further skills in (sustainable) tourism product or service development.

The study's main contribution is that it begins to fill a research gap concerning the need to determine, within the context of sustainable tourism development and the sustainable livelihoods approach, whether access to, and availability of, information and education and training has an impact on the survival of communities. Although Nzama (2008) has determined the existence of biodiversity-related programs offered by the iSimangaliso Authority to community members working in the Wetland Park, the availability of such courses for unemployed impoverished community members within and on the buffer zone of the Park does not appear to exist. This current study therefore emphasises that unemployed community members have no access to such programs and that they do not have information about them.

One aspect of this new contribution is that little research has been undertaken to date on a broad spread of the communities living adjacent to and within the iSimangaliso Wetland Park, although some authors have focused on certain areas within and on the Park's buffer zone (Gumede, 2009; Juru, 2012; Mhlongo, 2011; Nzama, 2008).

The need to preserve the iSimangaliso Wetland Park for future generations ensuring environmental sustainability was expressed by all stakeholders, but this can only come to fruition if communities are able not merely to sustain their livelihoods but also to improve them through skills development. The authorities, from local to government level, must take ownership in alleviating the poverty of rural communities by developing and implementing realistic strategies. Although the iSimangaliso Authority has many initiatives, these do not 
seem to filter through to the larger KwaZulu-Natal rural impoverished communities living adjacent to the Wetland since the local people do not seem to be aware of the initiatives.

It is crucial to integrate biodiversity conservation and sustainable livelihoods for all communities living within and around world heritage sites in order to achieve broad-based participation of local communities in the protection and management of the world heritage resource, as well as provide rural communities with skills training in aspects of tourism for them to access the tourism industry on different levels.

Education, training, job creation and access to job opportunities was shown to be imperative in the chosen case study area, and the "livelihood strategy" (Tao \& Wall, 2009) currently appears the most realistic approach. Economic prosperity can only be realized once relevant skills development has taken place. The lack of trained human resources results in many lost opportunities, such as local festivals and traditions that could be used successfully to promote conservation of the environment and to attract tourists (Dlamini, 1999; Zibani, 2002).

Lack of access to relevant information and training may well be the foremost reason why rural communities cannot break out of the poverty cycle. Information on all levels, from preschool to school, to economically active adults and to pensioners, is imperative for decision making and problem solving and for developing a skilled workforce. Access to relevant information, and education on how to use it, are key to raising poor communities from their dire conditions of mere survival and to helping them towards sustainable livelihoods in the long term.

In cases where positive livelihoods benefits do emanate from tourism and environmental conservation, there needs to be a deliberate process of ensuring an equitable distribution of benefits within the community. To assume that benefits will accrue equally to community members is naïve and negligent, and it assumes that a community is a homogenous entity. The reality of any community is obviously different, replete with power struggles, internal tensions and different levels of access to benefits (Juru, 2012). Local municipalities in Maputaland need to work closely with community structures to ensure that weak and 
marginalised groups do receive benefits emanating from the conservation and tourism sector. This goal will most likely be achieved through establishing equal representation in the local community council structures that make decisions regarding benefit sharing.

The study concludes that, where it is a matter of survival for rural communities, a sustainable livelihoods approach may be more appropriate and attainable than a sustainable tourism development approach. This is due to the fact that most of the respondents in the study were unemployed and were barely surviving, and thus in the short term it would be more realistic for these communities to pursue a livelihoods approach that is sustainable through information or educational programs concerning, for example, growing vegetables for their own use, or making bricks to build houses, but in a sustainable manner, and also not through depleting the resource base by using wood from forest trees or over-fishing the lake. Once these communities have attained sustainable livelihoods, it may then be feasible for them to then pursue sustainable tourism development activities. But then too there will be an important need for information and training from the authorities and other stakeholders about, for example, growing vegetables for local restaurants, making bricks for proposed ecolodges, or becoming guides during the fishing seasons. There is also a need for females to cocreate through involving tourists to weave baskets, do beadwork or prepare traditional cuisine.

In conclusion, sustainable tourism practice, especially in protected areas, remains a very complex issue and success will depend largely on access to relevant information and training, and on the level of involvement and empowerment of local communities in eradicating poverty and ensuring environmental sustainability. The iSimangaliso Wetland World Heritage Site will only be conserved for future generations by good governance and good management, and these are topics that require further research. The UNDP's criteria for good governance (UNDP, 1997) suggest fruitful issues and themes for future research, and they can be combined with the United Nations' Millennium Goals. 


\section{References}

Apleni, L. (2013). A missed opportunity: Community participation in tourism in South Africa. A Policy Brief: Sustainable Development Programme, Africa Institute of South $\begin{array}{llll}\text { Africa. } & \text { Retrieved } & 1 & \text { August }\end{array}$ http://led.co.za/sites/led.co.za/files/cabinet/orgnameraw/document/2013/42917_aisa_policy_brief-_erln.pdf

Arcodia, C., \& Whitford, M. (2006). Festival attendance and the development of social capital. Journal of Convention and Event Tourism, 8(2), 1-18.

Ashley, C., \& Jones, B. (2001). Joint ventures between communities and tourism investors: Experience in southern Africa. International Journal of Tourism Research, 3(2).

Botha, M. (2006). Measuring the effectiveness of the women entrepreneurship programme, as a training intervention, on potential, start-up and established women entrepreneurs in South Africa. DCom thesis, University of Pretoria, South Africa.

Bramwell, B \& Lane, B. (1993). Rural Tourism and Sustainable Development. Philadelphia: Channel View Publications.

Bramwell, B., \& Lane B. (2011). Critical research on the governance of tourism and sustainability. Journal of Sustainable Tourism, 19(4-5), 411-422.

Briggs, P. (2006). Greater St. Lucia Wetland Park. Johannesburg: 30 Degree South Publishers.

Cater, C., \& Low, T. (2012). Focus groups, in handbook of research methods. In L. Dwyer, A. Gill \& N. Saatarem (Eds.), Tourism: Quantitative and qualitative approaches (pp. 352-364). Cheltenham: Edward Elgar. 
Chambers, R., \& Conway, G.R. (1992). Sustainable livelihood: Practical concepts for the 21st century. IDS discussion paper 296. Institute of Development Studies, University of Sussex, Brighton.

Department of Environmental Affairs and Tourism (DEAT)(1996). The development and promotion of tourism in South Africa, White Paper, Government of South Africa.

Department of Environmental Affairs and Tourism (DEAT)(1997). Tourism in GEAR:

Tourism Development Strategy 1998-2000.

Department of Environmental Affairs \& Tourism (DEAT)(1998). Coastal policy Green

Paper: Towards Sustainable Coastal Development in South Africa. Pretoria, South Africa.

Department of Environmental Affairs and Tourism (DEAT)(2002). National Responsible Tourism Development Guidelines for South Africa. Accessed on 9 September 2015 fromhtpps://tkp.tourism.gov.za/documents/responsible\%20tourism\%20\%guidelines.pdf Department of Economic Development and Tourism. (DEAT)(2009) Kwazulu-Natal Provincial Government, South Africa. Annual Report 2009/2010.

Department of Trade and Industry (DTI)(2013). Industrial Policy Action Plan: Economic Sectors and Employment Luster, IPAP2013/14-2015/16, Accessed on 9 September 2015 from http://www.thedti.gov.za/news2013/ipap_2013-2013-1016.pdf

Dearden, P., Bennet, M., \& Johnston, J. (2005). Trends in global Protected Area governance, 1992-2002. Environmental Management, 36, 89-100.

Dlamini, L.P.P. (1999). The potential of culture and religious celebrations, festivals and sporting events in the marketing of tourism. Master's thesis, University of Zululand, Durban. 
Drexhage, J., \& Murphy, D. (2010). Sustainable development: From Brundtland to Rio 2012. Background $\quad$ paper. UN Headquarters, New York.

Duffy, R. (2001). Peace Parks: The Paradox of Globalisation. Geopolitics, 6 (2): 1-26.

Du Plooy, G.M. (2009). Communication research: Techniques, methods and applications. Lansdowne: Juta.

Eagles, P.F.J., Romagosa, F., Buteau-Duitschaever, W.C., Havitz, M., Glover, T.D., \& McCutcheon, B. (2013). Good governance in protected areas: An evaluation of stakeholders' perceptions in British Columbia and Ontario Provincial Parks. Journal of Sustainable Tourism, 21(1), 60-79.

Ellis, F. (2000). Rural livelihoods and diversity in developing countries. Oxford: Oxford University Press.

Ellis, F. (2006). Agrarian change and rising vulnerability in rural sub-Saharan Africa. New Political Economy, 11(3), 387-397.

Ezemvelo KZN Wildlife (EKZNW). (2010). Five Year Strategic Plan and Performance Plan 2009 -2014. Pietermaritzburg, South Africa.

Ezemvelo KZN Wildlife (EKZNW). (2011). Managing our Biodiversity Report. Pietermaritzburg, South Africa.

Fairer-Wessels, FA 1990. Basic community information needs of urban balck women $n$ Mamelodi, South Africa. South African Journal of Library and Information Science, 58(4):359-369. 
Giampiccoli, A. (2010). Globalisation, development, and community-based tourism in developing countries: A case study of Pondoland, Eastern Cape. Master's thesis, University of KwaZulu-Natal, Durban.

Giampicoli, A. \& Kalis, J. H. (2012). Community-Based Tourism and Local Culture.The case of the amaMpondo. Pasos, 10 (1): 173 - 188.

Gibbs, C. \& Keys, E. (2010). The Illusion of Equity: An Examination of Community Based Natural Resource Management and Inequality in Africa. Geography Compass, 4 (9): 1324-1338.

Govender-Van Wyk, S. (2007). Community-based sustainable tourism on commonages: An alternative to traditional land reform in Namaqualand, Northern Cape Province. Doctoral thesis, University of Pretoria. Retrieved 8 April 2014,http://upetd.up.ac.za/thesis/available/etd-05162007-171217/

Government of South Africa (1996). White paper. The development and promotion of tourism in South Africa. Department of Environmental Affairs and Tourism. May $\begin{array}{llll}\text { 1996.Accessed } & \text { on } & 9 & \text { September }\end{array}$ http://www.tourism.gov.za/AboutNDT/Publications/Tourism\%White\%paper.pdf.

Gumede, Z.S. (2009). Tourism participation in the iSimangaliso Wetland Park: Perceptions, practices and prospects. Master's thesis, Department of Recreation and Tourism, University of Zululand.

Hall, Michael. (2001). Trends in Ocean and Coastal Tourism: The End of the Last Frontier. Ocean and Coastal Management, 44 (2001): 601-618. 
Harbison, F.H. (1973). Human resources as the wealth of the nations. New York: Oxford University Press.

Hill, T., Nel, E., \& Trotter, D. (2006). Small-scale, nature-based tourism as a pro-poor development intervention: Two examples in KwaZulu-Natal, South Africa. Singapore Journal of Tropical Geography, 27(2), 163-175.

Hopwood, B., Mellor, M., \& O’Brien, O. (2005). Sustainable development: Mapping different approaches. Sustainable Development, 13(1), 38-52.

Jacobs, P., \& Makaudze, E. (2012). Understanding rural livelihoods in the West Coast District, South Africa. Development Southern Africa, 29(4), 574-587.

Jamal, T. \& Stronza, A. (2009). Collaboration theory and tourism practice in protected areas: stakeholders, structuring and sustainability. Journal of Sustainable Tourism, 17(2), 169-189.

James, B. (2012). Personal communication with Bronwyn James, Senior manager, Policy, Planning, Research and Development, iSimangaliso Wetland Park Authority. St Lucia. 7 August 2012.

Jiyane, G.V., \& Fairer-Wessels, F.A. (2012). Dissemination of information on climate change: A case study of women mussel harvesters at KwaNgwanase in KwaZuluNatal. Mousaion, 30(1), 19-38.

Jones, J (2006). Who benefits from "conservation and development"? The political ecology of biodiversity in KwaZulu-Natal, South Africa. Centre for Environmental Studies. University of Pretoria, South Africa.

Juru, S. T. (2012). The interaction between environmental conservation, tourism and rural coastal livelihoods: a case study of the Coastal region of Maputaland, South Africa. MA (International Development Studies). Halifax (NS): Saint Mary's University. 
Keyton, J. (2011). Communication research: Asking questions, finding answers. New York: McGraw-Hill.

Kuhn, L. (2007). Sustainable tourism as emergent discourse, world futures. Journal of New Paradigm Research, 63, 286-297.

Larlham, P. (1981). Festivals of the Nazareth Baptist Church. The Drama Review, 25(4), 5974. African Performance Issue.

Lee, S., \& Jamal, T. (2008). Environmental justice and environmental equity in tourism: Missing links to sustainability. Journal of Ecotourism, 7, 44-67.

Manwa, H. (2014). Impacts of Lesotho Highlands Water Project on sustainable livelihoods. Mediterranean Journal of Social Sciences, 5(15), 640-647.

Mazibuko, N.P. (2000). Community participation in tourism development at KwaNgcolosi, KwaZulu-Natal. Master's thesis, University of Zululand, South Africa.

Mbatha, N. (2011). Sharing benefits from coastal resources with rural communities in South Africa. The influence of Institutional Arrangements. University of Cape Town.

Mhlongo, S.K. (2011). Environmental management plan as a tool for tourism development within. Master's thesis, Department of Recreation and Tourism, University of Zululand, South Africa.

Mitchell, J. (2012). Value chain approaches to assessing the impact of tourism on low-income households in developing countries. Journal of Sustainable Tourism, 20(3), 457-475.

Muhanna, E. (2008). The contribution of sustainable tourism development in poverty alleviation of local communities in South Africa. Journal of Human Resources in Hospitality \& Tourism, 6(1) 37-61. 
Nzama, A.T. (2008). The nexus between sustainable livelihoods and ecological management of the World Heritage Sites: Lessons from iSimangaliso World Heritage Park, South Africa. Inkanyiso, Journal of Human and Social Sciences, 1(1), 34-41.

Okazaki, E. (2008). A community-based tourism model: Its conception and use. Journal of Sustainable Tourism, 16(5), 511-529.

Prentice, R., \& Andersen, V. (2003). Festivals as creative destinations. Annals of Tourism Research, 30(1), 7-30.

Qua-Enoo, G.A. (2001). Uplifting the informal entrepreneurs to mainstream business enterprises. Eastern Cape Technicon, Department of Accounting.

Republic of South Africa. (2001). New Growth Path (NGP) Booklet 1, accessed on 10 September 2015 from http://www.economic.gov.za/communications/publications/new-growth-pathseries/download

Republic of South Africa, Department of Tourism. (2010). National Growth Sector Strategy, http://www.tourism.gov.za/AboutNDT/Brances1?knowledge?Documents?National\% 20Tourism\%20Sector\%20Strategy.pdf

Republic of South Africa, Department of Tourism (DoT).(2015). Framework for community based tourism, March 2015.

Rogerson, C.M., \& Visser, E. (Eds). (2004). Tourism development issues in contemporary South Africa. Pretoria: Africa Institute of South Africa.

Ruhanen, L. (2013). Local government: Facilitator or inhibitor of sustainable tourism development? Journal of Sustainable Tourism, 21(1), 80-89.

Saarinen, J. (2010). Local tourism awareness: community views in Katutura and King Nehale Conservancy, Namibia. Development Southern Africa, 27(5), 713-724. 
Scoones, I. (1998). Sustainable rural livelihood: A framework for analysis. IDS Working Paper 72. Institute of Development Studies, University of Sussex, Brighton.

Scoones, I. (2009). Livelihoods perspectives and rural development. Journal of Peasant Studies, 32(1), 171-196.

Spenceley, A. (2005). Nature-based tourism and environmental sustainability in South Africa. Journal of Sustainable Tourism, 13(2), 136-170.

Spenceley, A., \& Meyer, D. (2012). Tourism and poverty reduction: Theory and practice in less economically developed countries. Journal of Sustainable Tourism, 20(3), 297317.

Statistics South Africa. (2004). Provincial Profile 2004, KwaZulu-Natal. www.statssa.gov.za/publications/Report-00-91-05/Report-00-91-052004.pdf. Retrieved 15 September 2015.

Tao, T.C.H., \& Wall, G. (2009). Tourism as a sustainable livelihood strategy. Tourism Management, 30, 90-98.

Tosun, C. (2000). Limits to community participation in the tourism development process in developing countries. Tourism Management, 21, 613-633.

Tsaur, S-H., Lin, Y-C., \& Lin, J-H. (2006). Evaluating ecotourism sustainability from the integrated perspective of resource, community and tourism. Tourism Management, $27,640-653$.

United Nations (UN). (1987). Brundtland Report. Report of the World Commission on Environment and Development: Our common future. Retrieved 1 August 2014,http://conspect.nl/pdf/Our_Common_Future Brundtland_Report_1987.pdf

United Nations (UN). (2010). Millennium Development Goals. Retrieved 1 August 2014, www.un.org/millenniumgoals/ 
United Nations (UN). (2011). Climate Change Conference, Durban 2011. Retrieved 2 August 2014,http://unfccc.int/meetings/durban_nov_2011/meeting/6245.php

United Nations Conference on Environment and Development (UNCED). 1992. Rio Summit. June 1992.

UNDP (United Nations Development Programme). (1997). New York. Hdr.undp.org/sites/default/files/reports/258/hdr_1997_en_complete_nostats.pdf

UNEP \& UNWTO (United Nations Environment Programme \& United Nations World Tourism Organisation) (2005). Making tourism more sustainable: A guide for policy makers. Retrieved 4 April 2014, www.unep.fr/shared/publications/pdf/DTIx0592xPA-TourismPolicyEN.pdf

United Nations Children's Fund (UNICEF). (2007). Water, sanitation and hygiene. Annual report. New York: UNICEF.

United Nations Scientific and Cultural Organisation (UNESCO). www.whc/unesco.org/en/list/914. Retrieved 13 September 2015.

United Nations World Tourism Organisation (UNWTO) (2000). http://www2.unto.org/ Retrieved 6 August 2014.

Van Rooyen, J.C. (2003). Rural community participation in tourism-based developments: The case of the Mbila community in Maputuland, KwaZulu-Natal. Master's thesis, University of Pretoria, South Africa.

Van Zyl, C., \& Botha, C. (2004). Motivational factors of local residents to attend the Aardklop National Arts festival. Event Management, 8, 213-222.

Woodley, A. (1993). Tourism and sustainable development: The community perspective. In J. Nelson, R. Butler, \& G. Wall (Eds), Tourism and sustainable development 
monitoring, planning, managing (pp 135-147). Heritage Resources Centre, University of Waterloo, Ontario.

World Bank. (1996). Towards Environmental Sustainable Development in Sub Saharan Africa: A World Bank Agenda. World Bank Publication.

WTTC (World Travel and Tourism Council). (2013). Tourism for tomorrow: The WTTC perspective. $\quad$ www.wttc.org/our-mission/strategic-priorities/tourism-tomorrow/. Retrieved 10 July 2014.

WWW.labour.gov.za. Retrieved 8 August 2014.

WWW.whc.unesco.org/en/list/914. Retrieved 8 August 2014.

Zibani, A.N. (2002). Zulu cultural traditions: A draw card for tourism in KwaZulu-Natal, with special reference to the Lebombo Spatial Development Initiative. Doctoral thesis, University of Zululand, South Africa.

\section{Biosketch}

Felicite Fairer-Wessels is an Associate Professor in Tourism Management in the Faculty of Economic and Management Sciences at the University of Pretoria, South Africa. She holds a $\mathrm{PhD}$ in Information Science and she conducts research concerning the dissemination of information in the areas of community development, ecotourism and heritage sites. 